\title{
地震時に風化軟岩層理面をすべり面として発生した高速地すべりの発生機構 Mechanism of earthquake-induced rapid landslides occurring along the bedding plane of weathered soft rock
}

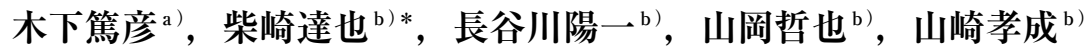 \\ Atsuhiko KINOSHITA, Tatsuya SHIBASAKI, Yoichi HASEGAWA, Tetsuya YAMAOKA and Takanari YAMAZAKI
}

\begin{abstract}
In recent earthquake events in Japan, many largely-displaced landslides occurred on dip slopes of Neogene sedimentary rocks. In this study, in order to examine the mechanism of earthquake-induced landslides, we took Nigorisawa landslides which occurred in the 2008 Iwate-Miyagi Nairiku earthquake for the research site, and investigated physical and mechanical properties of slip surface soils existing along the bedding plane. Results of ring shear tests performed under shear speeds ranging from 0.02 to $500 \mathrm{~mm}$ /min revealed that shear strength decreases during high shear rates. To clarify the mechanism of the negative rate effect, additional experiments were performed on medium-plasticity cohesive soils. Test results showed that weakening of shear strength is likely to occur when the shear box bath is filled with water. On the other hand, a long-time fast shearing test under drained condition suggests that shear weakening did not continue and strength recovery gradually occurred due to dissipation of excess pore water pressure. Temporal increase in water content within shear zone is an essential cause for strength weakening during fast shearing. In addition, according to field survey on groundwater conditions, water flow is significant just above the bedding plane, possibly influencing on shear weakening of slip surface soils during the earthquake.

Key words : Bedding plane, Residual strength, Rate dependency, Pore water pressure, Earthquake-induced landslide

\section{和文要旨}

近年の地震によって, 新第三系堆積岩の流れ盤斜面で, 大移動を伴う地すべりが数多く発生している。本研究では, 2008年岩手・ 宮城内陸地震で発生したニゴリ沢地すべりを調査地として，すべり面となった風化軟岩の層理面沿いに分布する粘性土の物理・力 学特性を調査し, 地震時の地すべりの発生機構を検討した。リングせん断試験により残留強度の速度効果を $0.02 \sim 500 \mathrm{~mm} / \mathrm{min}$ の範 囲で検討した結果，せん断速度を上昇するとせん断強度が急激に低下する見かけの負の速度効果が確認された。液性限界50\%前後 の中塑性の粘性土を用いた検証実験によると，せん断強度の低下は供試体を浸水させた条件で起きやすく，排水を許しながら高速 せん断を長時間継続すれば，過剩間隙水圧の消散とともにせん断強度が回復する特性も確認された。高速せん断時の強度低下は， 供試体のせん断ゾーンの含水比が一時的に増加して軟質化することが大きな要因と考えられる。また, 現地での地下水調查の結果 によると，すべり面を形成した層理面直上において，顕著な地下水流動が確認された。このような地下水環境が，地震時の風化軟 岩層理面の強度低下と地すべりの大移動に強く関わっている可能性がある。
\end{abstract}

キーワード：層理面, 残留強度, 速度依存性, 間隙水圧, 地震地すべり

\section{1. はじめに}

リングせん断試験機を用いて粘性土を中心とした土の せん断強度のせん断速度依存性に関する検討を行った Tika et al. (1996) の研究によると，せん断速度上昇に よりせん断強度が低下を示す「負の速度効果 (negative rate effect)」, 高速せん断時に強度が高まる「正の速度 効果 (positive rate effect)」, 低速時と高速時の強度に 差がない「中立の速度効果 (neutral rate effect)」の特 性に分類される。筆者らは，2004年新潟県中越地震によ り発生した塩谷神沢川地すべりの発生機構検討を目的に, すべり面の土質特性に関する調査を行った（木下ら， 2009）。すべり面構成土である液性限界50\%前後の粘性 土を用いた $0.02 〜 500 \mathrm{~mm} / \mathrm{min}$ の低速〜準高速のリング せん断試験の結果によると，せん断速度上昇によりせん 断強度が大きく低下する負の速度効果を確認した。地震 時に高速・長距離移動を伴う地すべりの発生要因として,

* 連絡著者/corresponding author

a) 林野庁治山課 (現所属: 国土交通省近畿地方整備局)

Forestrty Agency (Now in Kinki Regional Development Bureau, Ministry of Land, Infrastructure, Transport and Tourism)

b ) 国土防災技術株式会社

Japan Conservation Engineers Co., Ltd

T960-0112 福島県福島市南矢野目字清水前 34 番地 12

34-12, Shimizumae, Minami-yanome, Fukushima City, Fukushima Prefecture, 9600112, Japan
上述の土質特性が大きな影響を与えた可能性を指摘した。 國生ら（2010）は，地震によって長距離移動を起こす 地すべりの原因は，地すべり土塊を動かす地震慣性力の 直接的な効果よりも，震動による間隙水圧の上昇などに よって材料強度が弱まる効果や，いったん滑りが始まっ た後での一方向へのせん断や擋乱による地盤強度の大幅 な低下が主因であることを指摘している。粘性土の残留 強度の負の速度効果は, いったん滑りが始まった後での 強度低下に相当し，地震時の長距離移動の発生を決定す る本質的な要因となることから，メカニズムの詳細解明 が必要である。

土の残留強度の速度効果に関する近年の研究によれば, 齋藤ら（2007）は，ベントナイト・珪砂混合土の非排水 リングせん断試験を実施し，せん断中に計測された間隙 水圧を評価して, せん断速度に応じて有効内部摩擦角が 大きく変化すると考察している。粘性土のせん断強度が せん断速度により変化するメカニズムとして, 過剩間隙 水圧の変化ではなく，せん断モードの変化が主因である ことを推定している。また, 王ら（2010）も, 風化蛇紋 岩の実験より, 地すべりが高速化に至らなかった要因と して正の速度効果を確認し, 速度依存性の原因として, 
せん断ゾーンの構造変化の影響に注目した。

負の速度効果のメカニズムを検討したTika et al. （1996）の研究では，せん断箱を収めた水槽に水を満た した場合と満たさない場合（供試体を浸水させた条件と 浸水させない条件）で，残留強度特性が変化する実験結 果を示している。せん断速度上昇により，せん断ゾーン 内の土粒子が他の土粒子を乗り越えやすくなり，せん断 ゾーンの空隙が多くなる。この空隙に外部から自由水が 浸入することで含水比が増大し, せん断ゾーンが流動化 し，せん断強度が低下したものと考察している。筆者ら （木下ら；2009）が報告した塩谷神沢川地区の試料での 実験結果も，供試体を水槽内で浸水させた条件で試験を 行ったため, Tika et al. (1996) が述べた上記現象が起 きた可能性が考えられる。

2004年新潟県中越地震では，粘土粒子を主要構成粒子 とする泥岩よりも，シルト粒子を主体とするシルト岩・ 砂質泥岩の分布域で地すべりが数多く発生したとういう 特徴がある。本研究では，2008年岩手・宮城内陸地震に おいて発生した第三紀層の地すべりにおいて，すべり面 の物理特性を把握し，現状のすべり面の強度特性と残留 強度の速度効果について検討を行った。加えて，負の速 度効果を示す代表的な土質試料について，強度低下要因 を検討するためのリングせん断試験も行い，供試体の含 水比や間隙水圧の挙動を検証した。また，現地にて地下 水分布やその流動特性を調査し，地下水環境や土質条件 が地震地すべりの発生に与えた影響を考察した。

\section{2. 調査地の概要および調査内容}

\section{1 ニゴリ沢地区の概要}

調査地は，岩手県一関市厳美町の磐井川右岸支渓に面 する北〜東向き斜面で，2008年岩手 ・宮城内陸地震にお いて発生した 3 つの地すべりブロック（Ｉ， II， III ブロッ ク）である（図 -1 ，写真 -1 )。磐井川で大規模な河道 閉塞を起こした市野々原地区の地すべりの $0.7 〜 1.2 \mathrm{~km}$ 下流側に位置し，本震の震源からの距離は3.0〜 3. $5 \mathrm{~km}$ である。周辺の地層は，北東〜東向きに傾斜している。

図－2に，I， II ，III ブロックの平面図および縦断図 を示す。I ブロックの地すべり規模は，斜面長 $100 \mathrm{~m}$, 斜面幅 $200 \mathrm{~m}$ ，最大すべり面深度 $25 \mathrm{~m}$ であり，斜面途中 に押し出した土砂が渓流を埋め約 $10 \mathrm{~m}$ の河床上昇をもた らしている。落差 $20 \mathrm{~m}$ の滑落崖を有し，末端部では $30 \mathrm{~m}$ 以上の移動を示した。調査地を構成する地質は中新統下 嵐江層で，凝灰質のシルト岩を主体とする。すべり面は 流れ盤をなす特定の層理面に規制されている。やや右側 壁側に地層の最大傾斜方向をとり，左右非対称の地すべ り形状をとることが，集水井やコアのすべり面構造（最 大傾斜方向と擦痕との関係）からも確認されている（写 真 - $2 \mathrm{ABCD}) 。$ II ブロックは，斜面長 $110 \mathrm{~m}$ ，斜面幅140 $\mathrm{m}$ ，最大すべり面深度 $20 \mathrm{~m}$ である。地層の最大傾斜方向 に大きく斜交する方向に移動しており，末端部を埋めた

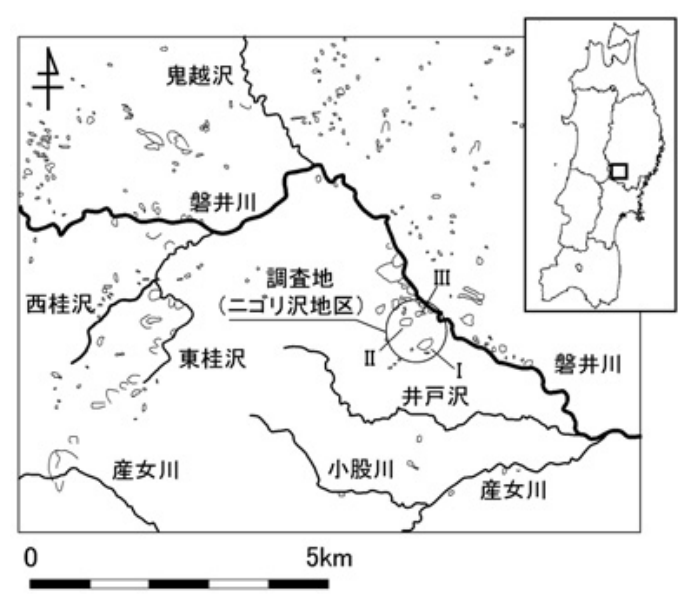

図ー 1 ニゴリ沢地すべりの位置図

Fig. 1 Location map of Nigorisawa landslides

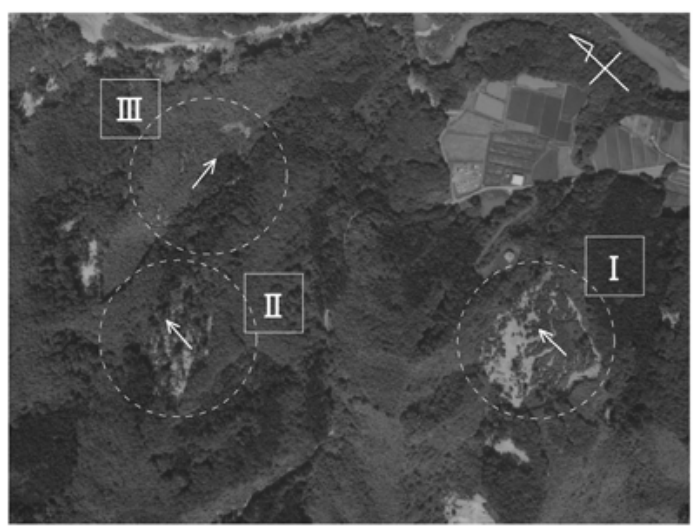

写真ー 1 ニゴリ沢地区の空中写真

(国土地理院撮影, CTO20083-C15(C 3 )-1576)

Photo 1 Aerial photo of the research site

谷幅より $20 \mathrm{~m}$ 前後の移動量が確認される。III ブロックは, 斜面長 $200 \mathrm{~m}$ ，斜面幅 $100 \mathrm{~m}$ ，最大すべり面深度 $16 \mathrm{~m}$ で， 尾根型斜面で発生した。谷側に開放した右側部には，す べり面が露岩しており，その走向傾斜はN $5{ }^{\circ} \mathrm{E} 22^{\circ} \mathrm{E} て ゙$, 地層の最大傾斜方向と移動方向がほぼ一致している。斜 面下部ではすべり面が深く潜り，末端部が大きな抵抗体 となっていていたことから，末端部の開放していた I， II ブロックほどの移動量は確認されなかった。3つのブ ロックとも地震により高速で移動したものと推察される が，滑動時の移動速度の詳細は不明である。

\section{2 調查内容}

ニゴリ沢地区のすべり面の土質特性を把握することを 目的に, 物理試験および力学試験を行った。物理試験は, すべり面周辺および移動体浅層部や基盤側に確認された 粘性土や風化岩を対象に，粒度試験および液性限界・塑 性限界試験をJIS規格に準拠して行った。力学試験は, $425 \mu \mathrm{m}$ 以下粒径分の調整擋乱試料によるリングせん断 試験と,不擋乱試料を対象としたすべり面せん断試験(眞 弓ら；2003，木下ら；2009）を行った。すべり面せん断 試験は， I ブロックのBV-1, BV-5 のボーリングコア， 

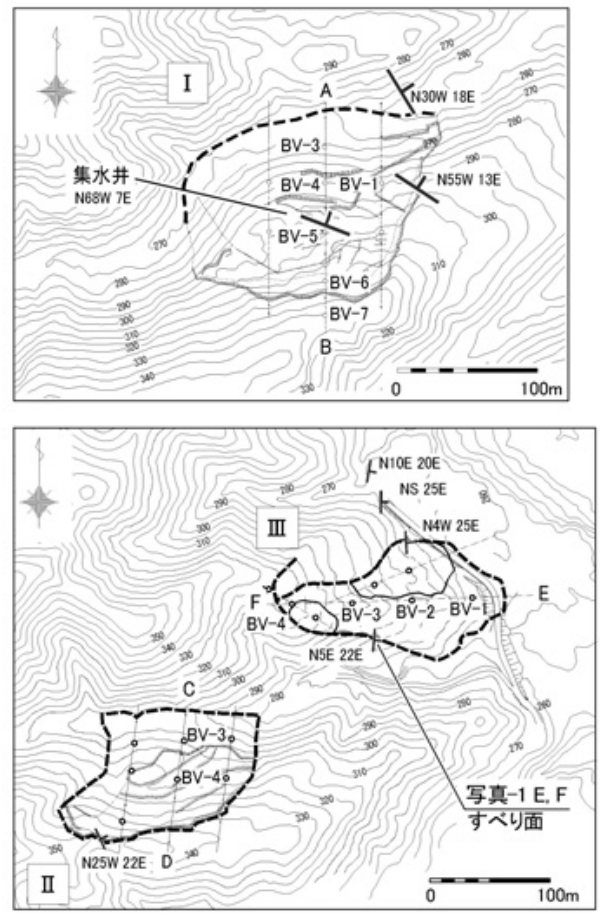

図ー2 ニゴリ沢地区地すべり（ I , I , III゙ロック）の平面図と縦断図

Fig. 2 Area map and main cross section of Nigorisawa landslides
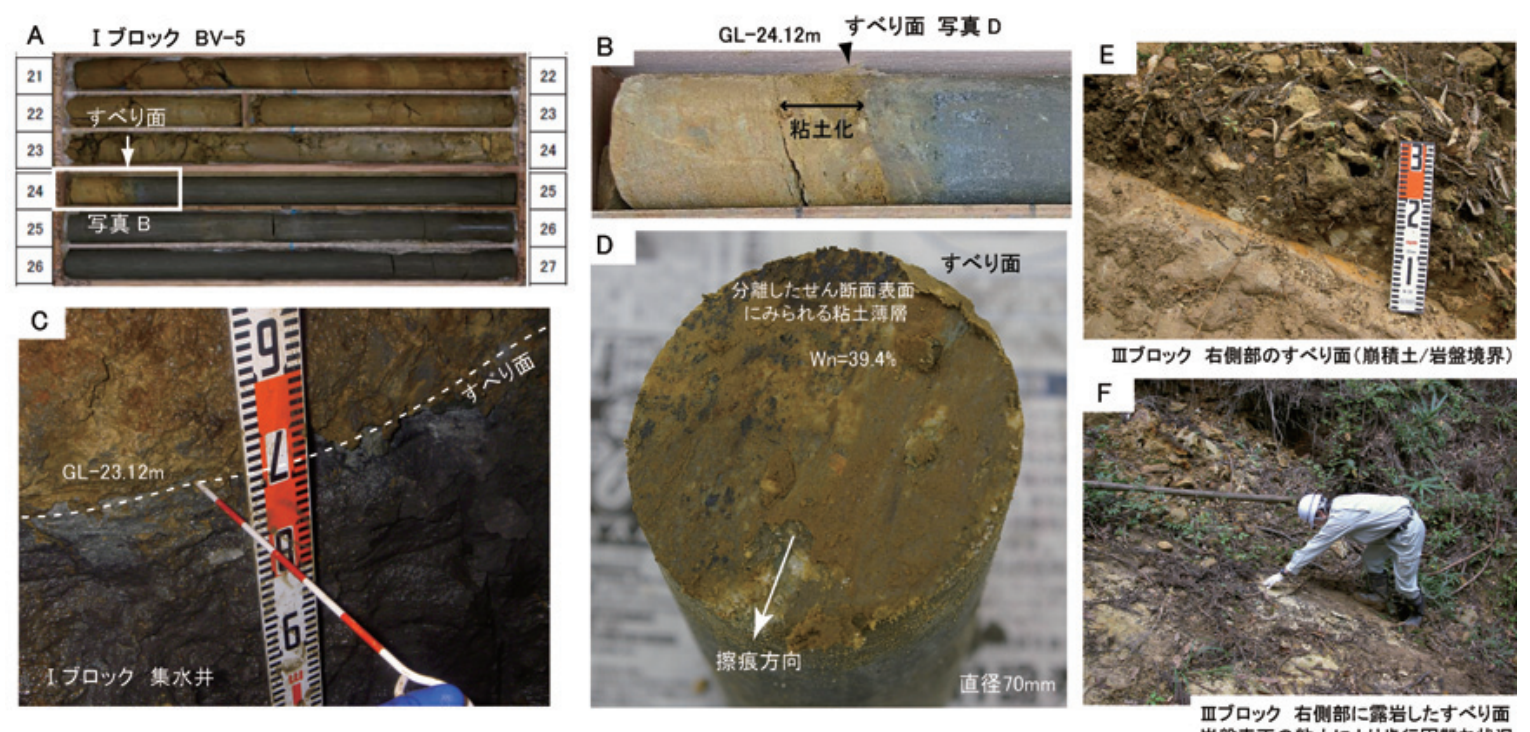

岩盤表面の船さにより歩行困能な状況

写真一 2 ニゴリ沢地区のすべり面

Photo 2 Slip surface of Nigorisawa landslides

III ブロック右側部の露頭より採取したすべり面を含む不 擋乱試料について，直径 $60 \mathrm{~mm}$, 高さ $20 \mathrm{~mm}$ のイズの 供試体で行った。 BV-5 試料および右側部試料について は，層理面を含む試料であるため，せん断面を確実に認 定することができた (写真 - 1 ) が，BV-1 試料は，せ ん断面が判然とせず，すべり面の認定が困難であった。

リングせん断試験は, 汎用的なBishop型リングせん 断試験機を用い, せん断速度 $0.02 \mathrm{~mm} / \mathrm{min}$ の排水条件で 静的な残留強度を求める試験と, せん断速度 $0.02 \mathrm{~mm} /$ $\min$ で残留せん断状態を確認後に, $5 \rightarrow 50 \rightarrow 500 \rightarrow 0.02$ $\mathrm{mm} / \mathrm{min}$ とせん断速度を上昇・低下させる実験を行った。 上限の $500 \mathrm{~mm} / \mathrm{min}$ は, 試験機のモーターの許容を考慮 して実験上決めたものであり, 実施の地すべりの移動速 度は，これよりも大幅に大きかったと推察される。供試 体のサイズは, 外径 $150 \mathrm{~mm}$, 内径 $100 \mathrm{~mm}$, 高さ $20 \mathrm{~mm}$ である。せん断面の隙間は，せん断開始直前にダイヤル ゲージの針の変位が視認できる数 $\mu \mathrm{m}$ 程度の極僅かな隙 間を与えた。

加えて, 地すべり移動体および基盤も含めた地盤特性 を明らかにするため，I ブロックの中央付近に位置する 
$\mathrm{BV}-5$ についてPS検層を行い，地盤の速度構造を把握 した。コアの重量計測，針貫入試験 $(10 \mathrm{~cm}$ 間隔)，含水 比計測，色彩值の計測を行い，コアの各種物性を調查し た。色彩值は，土色計（KONICA MINOLTA製SPAD503）を用い， L*a*b*表色系で計測を行った。

\section{3. ニゴリ沢地区の地盤特性とすべり面の土質特性}

\section{1 ニゴリ沢地すべりの地盤特性}

図- 3 に，I ブロック BV-5 号孔における弾性波速度, コア箱の重量より推定した密度，コアの針貫入勾配，含 水比，色彩值の計測結果を示した。弾性波速度は深部ほ ど速く，すべり面直下基盤岩のP波，S波速度は，2.6， $0.62 \mathrm{~km} / \mathrm{s}$ であった。密度は，すべり面を境に $0.3 \mathrm{~g} / \mathrm{cm}^{3}$ 以上の大きな変化を示し，基盤岩の密度は $2.0 \mathrm{~g} / \mathrm{cm}^{3}$ を 上回った。棒状コアを呈す基盤岩は，針貫入勾配は高い 值が続き，土砂状〜岩片状〜短棒状コアを呈す移動層は， 硬軟の変化の繰り返しが認められた。また，コアの含水 比は深部ほど小さく，黄色度の大きさを示す色彩值 $\mathrm{b} *$ の変化からも分かるように，移動層側は風化が進み全体 的に黄褐色化が進んでいる。

孔内水位は，すべり面以深に漏水している調査孔もみ られるが，I，II， III ブロックとも，すべり面の上下近 傍に水位が形成されている（図-2）。原岩色の未風化 岩の中に黄褐色化した層理面がすべり面となっている調 査孔も認められた。I ブロック BV-5号孔では，鏡肌 状を呈すせん断面が確認され，その移動層側は粘土化が 進み，含水比 $40 \%$ 程度のフィルム状粘土がせん断面を薄 く覆う様子を認めた（写真－2 D)。 III ブロック右側部 に露岩した層理面は，風化により表面が粘性土状に軟質 化しているため，人が直立困難なほど滑りやすい状態と なっていた $($ 写真 $-2 \mathrm{~F})$ 。図 - 5 は，I ブロック斜面 上部のBV-6 号孔で実施した地下水検層と高分解温度検 層の結果である。すべり面の延長上の層理面に顕著な地 下水流動が確認され，地震前からすべり面を形成した層
理面に沿って恒常的あるいは間歇的な地下水流動があっ たことが示唆される。

\section{2 ニゴリ沢地区すべり面の土質特性}

\subsection{1 物理特性と残留強度特性}

表－1に，I，III，III ブロックの，各種試験結果を示 す。写真－ 1 に示したように，明瞭なせん断面を有する I ブロック BV- 5 試料や III ブロックの右側壁試料では, すべり面せん断試験（眞弓ほか；2003）より，16台の せん断抵抗角を計測した。すべり面周辺や移動層から採 取した擋乱試料（ $425 \mu \mathrm{m}$ 以下粒径分）によるリングせ ん断試験からは, 残留せん断抵抗角 $\phi \mathrm{r}^{\prime}=15.4 \sim 26.9^{\circ}$ を計測し，その下限值は，すべり面せん断試験で求めた 現場残留強度值とほぼ一致した。

降雨・融雪を誘因とする第三紀層地すべりのすべり面 は，スメクタイトに富むすべり面粘土の残留強度特性に 強く影響を受けるため， $\phi^{\prime}=5^{\circ}$ 前後のせん断抵抗角を 示す事例が非常に多いことが指摘されている（眞弓ら， 2003）。ニゴリ沢地区のすべり面構成土は，塑性指数 26 ～75，粘土含有率21～64\%を示し（表一 1 ），木下ら （2009）が報告した中越地震の塩谷神沢川地区のすべり 面粘土よりも粘土含有率が高く，高塑性な粘性土が多く みられる。 $\phi \mathrm{r}^{\prime}$ は，塩谷神沢川地すべりで得られた $26^{\circ}$ 前後よりは小さいが，両地区のすべり面のせん断抵抗角 は，降雨・融雪を誘因とする第三紀層地すべりの一般值 $\left(\phi^{\prime}=5^{\circ}\right.$ 前後 $)$ よりも明らかに大きく，地震を誘因と した地すべりの特徵を示していると考えられる。

\subsection{2 残留強度の速度効果の検証}

ニゴリ沢地区すべり面粘土の残留強度のせん断速度依 存性を明らかにするため，I ブロックの 2 試料（BV-1, BV-5）を用いて実験を行った。木下ら（2009）の方法 に準じ，汎用的なBishop型リングせん断試験機（供試 体外径 $150 \mathrm{~mm}$ ，内径 $100 \mathrm{~mm}$ ）を用い, $0.02 \mathrm{~mm} / \mathrm{min}$ のせ ん断速度で残留せん断状態を確認した後に，せん断速度 を $5 \rightarrow 50 \rightarrow 500 \rightarrow 0.02 \mathrm{~mm} / \mathrm{min}$ と段階的に変更する実験
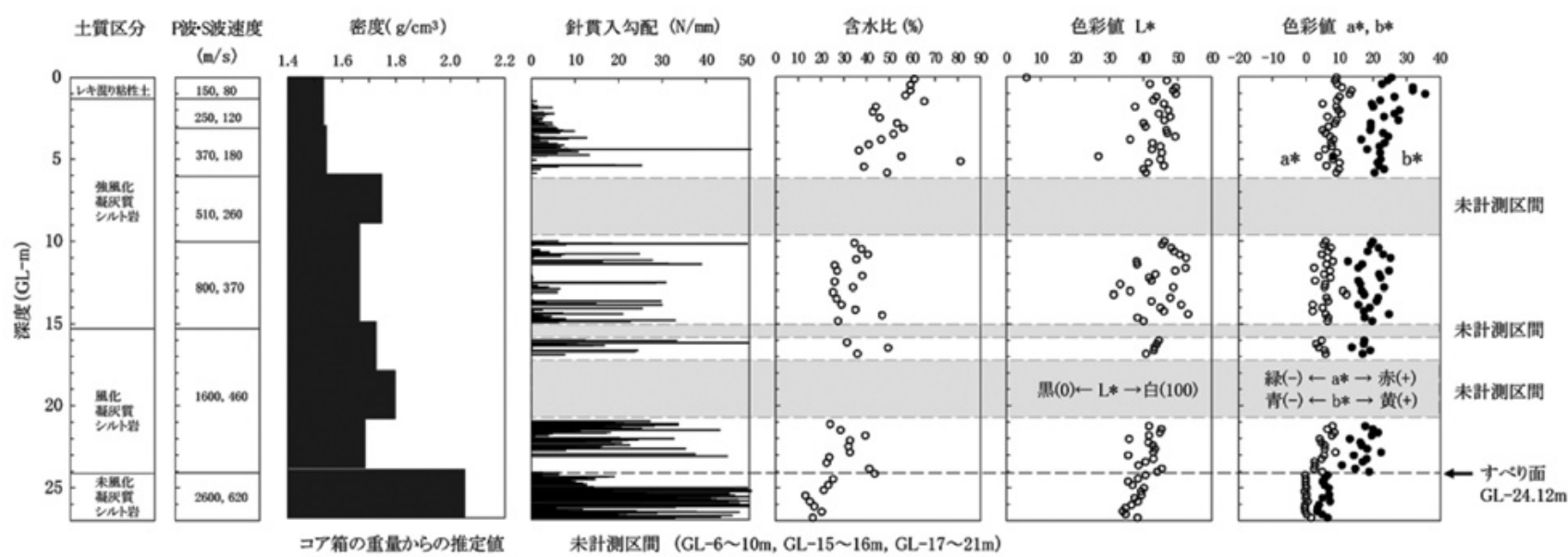

図ー3 I ブロックBV-5 号孔での孔内試験およびコアの物性計測の結果

Fig. 3 Depth profiles of results of borehole logging and tests on drilled core samples 
を，供試体を水槽内に浸水させた条件で行った（図－6）。 せん断速度を上昇させた瞬間に一時的なピーク強度を毎 回発現するが，せん断を継続すると50〜 $500 \mathrm{~mm} / \mathrm{min} の$ 高速条件でせん断強度の大きな低下が確認された（図一 7 )。中越地震により発生した塩谷神沢川地区の試験結 果（木下ら；2009）同様，負の速度効果が認められた。

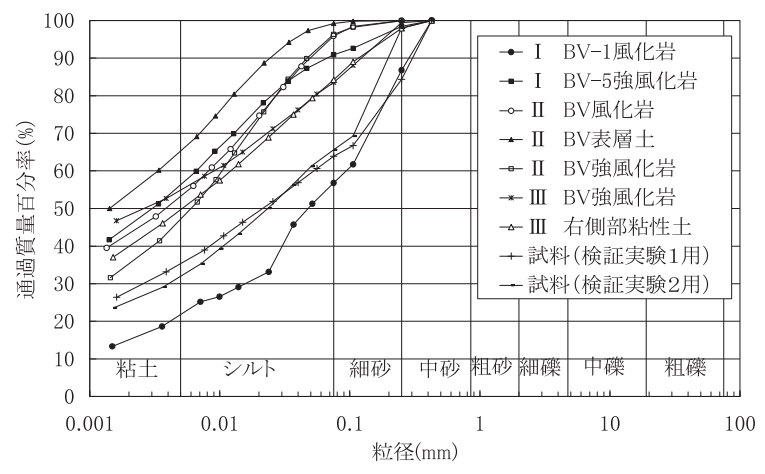

図-4 粒度分布

Fig. 4 Grain size distribution of soil samples

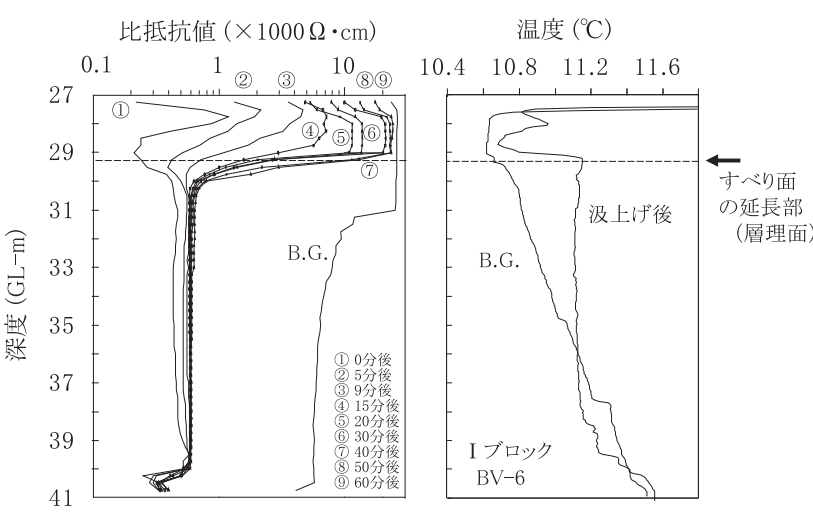

図－5 食塩水検層と高分解能温度検層の結果

Fig. 5 Results of groundwater prospecting and highresolution temperature logging
また，高速せん断終了後に, $0.02 \mathrm{~mm} / \mathrm{min}$ の低速条件に 戻すと，せん断速度変更前のレベルまで，強度の回復が 確認された。

\section{4. 中塑性粘性土の負の速度効果メカニズムの検証実験}

\section{1 負の速度効果を示す土質材料の特徵}

高速せん断時に顕著な強度低下を示す負の速度効果は, Skempton（1985）が報告したKalabaghダム試料の一部 や, Tika and Hutchinson (1999) が報告したVaiontダ ム試料にも認められている。これらは, 粘土分を20３0\% 程度含んだシルト分に富む粘性土であり, Tika et al. （1996）が示した多くのデー夕にも，負の速度効果は, シルト分に富む粘性土に認められる傾向がある。木下ら （2009）が報告した塩谷神沢川地区をはじめ，近年国内 で発生した地震地すべりのすべり面構成土のリングせん 断試験結果によると，負の速度効果は，中～低塑性の粘 性土に特徴的に見受けられる傾向にある(柴崎ら；2009）。 そこで，本研究では，そのメカニズムを検討するため， 負の速度効果を示すことが判明している物理特性が似 通った代表的な試料を用いて，2つの検証実験（実験1， 実験 2）を行った。

\section{2 せん断面への自由水浸入による強度低下の可能 性（検証実験 1 )}

Tika et al.(1996) は，水槽内の着色した水が高速せ ん断時に供試体のせん断ゾーンに取り込まれたという実 験結果を示している。図-7で示した実験が，水槽の水 がせん断強度の低下に影響を及ぼした可能性を検証する ため，高速せん断時に浸水した条件と浸水しない条件で のリングせん断挙動を比較し, 高速せん断直後のせん断 面の状態を観察した。実験に用いた試料は，2008年岩 手・宮城内陸地震において発生した宮城県栗原市南耕英 地区の崩壊地にて採取した火山灰質土（粒径 $425 \mu \mathrm{m}$ 以

表一 1 ニゴリ沢地区の土質試験結果

Table 1 Results of soil tests

\begin{tabular}{|c|c|c|c|c|c|c|c|c|c|c|c|}
\hline \multirow{2}{*}{\multicolumn{3}{|c|}{$\begin{array}{l}\text { ブロック } \\
\text { 調査位置 }\end{array}$}} & \multicolumn{4}{|c|}{ I ブロック } & \multicolumn{3}{|c|}{ II ブロック } & \multicolumn{2}{|c|}{ III ブロック } \\
\hline & & & \multicolumn{2}{|c|}{ BV -1} & \multicolumn{2}{|c|}{$B V-5$} & BV -3 & 複数孔 & BV -1 & 複数孔 & $\begin{array}{c}\text { 右側部 } \\
\text { 露頭 }\end{array}$ \\
\hline \multicolumn{3}{|c|}{ 試験深度 } & $\begin{array}{l}9.4 \sim \\
10.5 \mathrm{~m}\end{array}$ & $15.92 \mathrm{~m}$ & $\begin{array}{l}22.8 \sim \\
24.0 \mathrm{~m}\end{array}$ & $24.12 \mathrm{~m}$ & $\begin{array}{l}2.0 \sim \\
4.0 \mathrm{~m}\end{array}$ & $\begin{array}{c}\text { すべり面 } \\
\text { 周辺 }\end{array}$ & $\begin{array}{l}11.5 \sim \\
12.0 \mathrm{~m}\end{array}$ & $\begin{array}{c}\text { すべり面 } \\
\text { 周辺 }\end{array}$ & 地表 \\
\hline \multicolumn{3}{|c|}{ 試料状態 } & 風化岩 & $\begin{array}{l}\text { 強風化· } \\
\text { 破砕岩 }\end{array}$ & 強風化岩 & $\begin{array}{c}\text { 不連続面 } \\
(\text { 鏡肌) }\end{array}$ & $\begin{array}{l}\text { 表層土 } \\
\text { (粘性土） }\end{array}$ & 強風化岩 & 風化岩 & 強風化岩 & $\begin{array}{l}\text { 粘性土// } \\
\text { 不連続面 } \\
\text { (鏡肌) } \\
\end{array}$ \\
\hline \multirow{6}{*}{$\begin{array}{l}\text { 物 } \\
\text { 理 } \\
\text { 特 } \\
\text { 性 }\end{array}$} & \multirow{3}{*}{$\begin{array}{c}\text { 粒度特性 } \\
(425 \mu \text { m以下粒径分) }\end{array}$} & 砂分 & 43 & & 9 & & 1 & 4 & 4 & 17 & 16 \\
\hline & & シルト分 & 36 & & 35 & & 35 & 50 & 43 & 29 & 35 \\
\hline & & 粘土分 & 21 & & 56 & & 64 & 46 & 53 & 54 & 49 \\
\hline & \multirow{3}{*}{ コンシステンシー } & $\mathrm{W}_{\mathrm{L}}(\%)$ & 62.8 & & 99.4 & & 126.3 & 79.7 & 50.8 & 117.1 & 99.5 \\
\hline & & $\mathrm{W}_{\mathrm{P}}(\%)$ & 32.4 & & 41.1 & & 51.3 & 44.3 & 24.7 & 51.5 & 64.7 \\
\hline & & IP & 30.4 & & 58.3 & & 75.0 & 35.4 & 26.1 & 65.6 & 34.8 \\
\hline \multirow{6}{*}{$\begin{array}{l}\text { 力 } \\
\text { 学 } \\
\text { 特 } \\
\text { 性 }\end{array}$} & \multirow{2}{*}{$\begin{array}{c}\text { 現場残留強度 } \\
\text { (す心゙り面せん断試験) }\end{array}$} & $\mathrm{C}^{\prime}(\mathrm{kPa})$ & & 22.0 & & 46.8 & & & & & 11.4 \\
\hline & & $\phi^{\prime}\left({ }^{\circ}\right)$ & & 26.6 & & 16.0 & & & & & 16.6 \\
\hline & \multirow{2}{*}{$\begin{array}{c}\text { 完全軟化強度 } \\
(425 \mu \text { m以下粒径分) }\end{array}$} & $\mathrm{Cs}{ }^{\prime}(\mathrm{kPa})$ & 5.5 & & 0.0 & & 0.0 & 0.0 & 0.0 & 0.0 & 0.0 \\
\hline & & $\phi s^{\prime}\left({ }^{\circ}\right)$ & 32.7 & & 32.7 & & 31.1 & 32.9 & 33.8 & 28.8 & 35.0 \\
\hline & \multirow{2}{*}{$\begin{array}{c}\text { 残留強度 } \\
(425 \mu \text { m以下粒径分) }\end{array}$} & $\mathrm{Cr}^{\prime}(\mathrm{kPa})$ & 10.8 & & 9.5 & & 11.1 & 13.9 & 16.0 & 12.2 & 3.9 \\
\hline & & $\left.\phi \mathrm{r}^{\prime}{ }^{\circ} \quad\right)$ & 25.6 & & 21.8 & & 22.5 & 23.6 & 26.9 & 15.4 & 16.7 \\
\hline
\end{tabular}


下に調整) である。木下ら（2012）が行った研究の一環 で採取した試料であり，試料の物理特性は，土粒子の密 度 $2.68 \mathrm{~g} / \mathrm{cm}^{3}$ ，粘土分 $34 \% ， シ ル ト$ 分 $29 \%$ ，砂分 $36 \%$ ， 液性限界 $44.9 \%$ ，塑性指数 13.9 である。

垂直応力 $100 \mathrm{kPa}$ で実験結果を図 -8 に示す。図一 8 (a) は浸水条件での実験結果であるが，ニゴリ沢地区 の図 - 7 の実験結果同様, $500 \mathrm{~mm} / \mathrm{min}$ でせん断強度が大 きく低下し，明瞭な負の速度効果が確認された。一方， 図-8 (b)は， $50,500 \mathrm{~mm} / \mathrm{min}$ の条件で，供試体を浸水 させずに実施した結果である。浸水条件に比べ，500 $\mathrm{mm} / \mathrm{min}$ での強度の低下幅が小さいことが分かる。高速 せん断直後に試料を観察したところ, 浸水条件の試料は, 数mm厚のせん断ゾーンが高含水状態で軟質化している

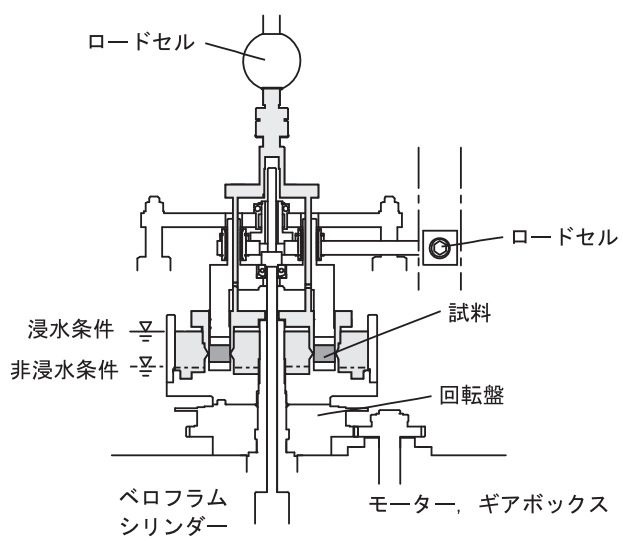

図一 6 沉用的なBishop型リングせん断試験機の模式図

Fig. 6 Schematic illustration of Bishop-type ring shear apparatus

(a) I ブロック BV-5 (GL-22.8〜24.0m)

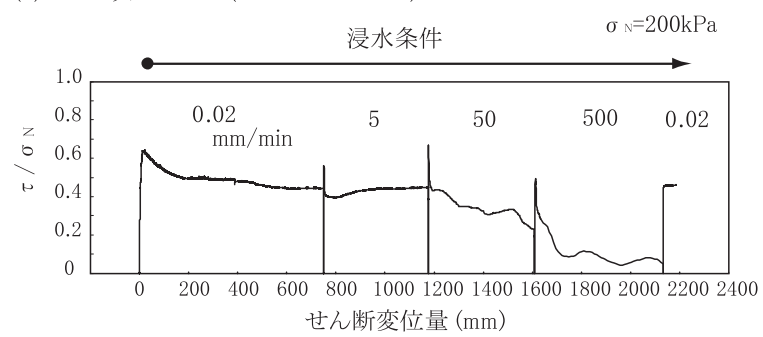

(b) I ブロック BV-1 (GL-9.4〜 10.5m)

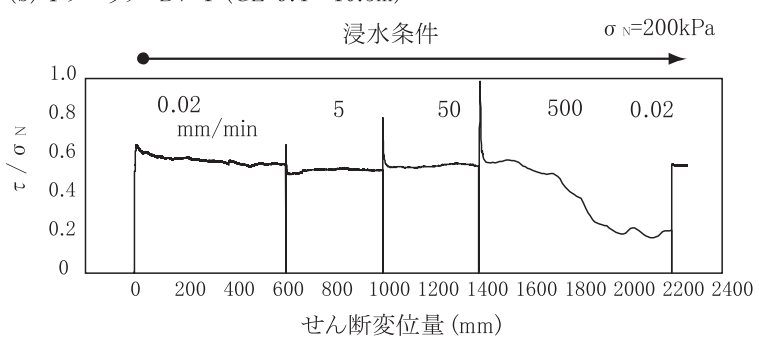

図ー7 Bishop型リングせん断試験による速度効果検証実験

Fig. 7 Results of velocity-stepping ring shear experiments
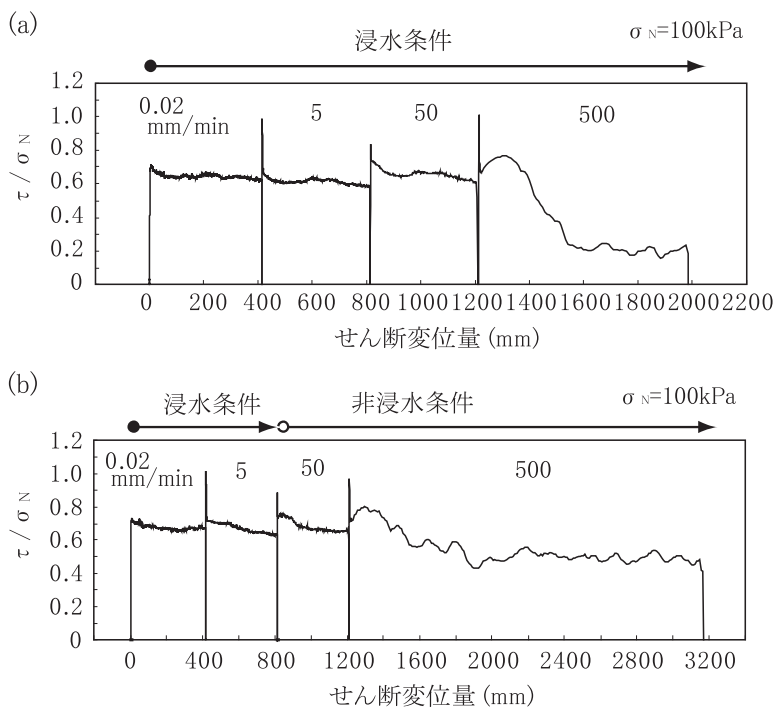

図－8Bishop型リングせん断試験による速度効果検証実験 (a：浸水条件, b：非浸水条件)

Fig. 8 Results of velocity-stepping ring shear experiments

( $a$ : water in the bath, $b$ : no water in the bath)

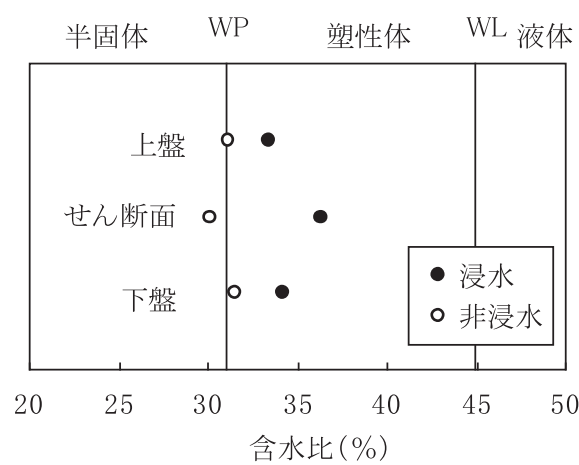

図-9 試験後試料の含水比（図一8の実験）

Fig. 9 Water contents of specimens around shear zone (data of the Fig. 8 experiment)

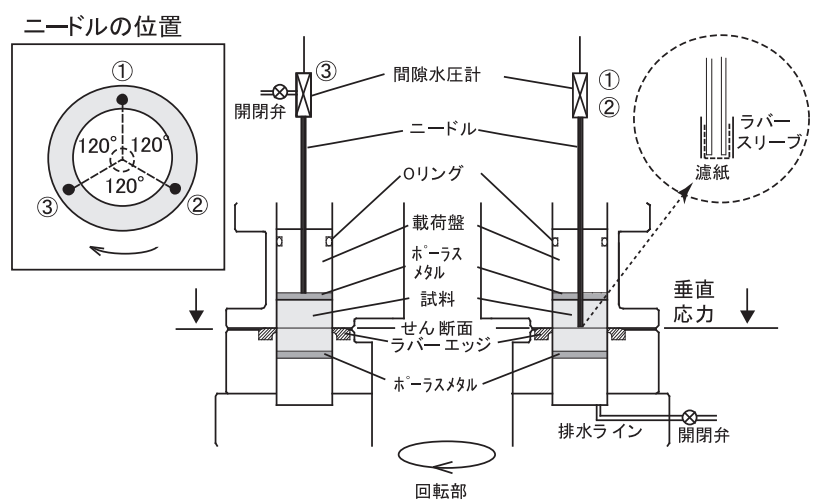

図一10 非排水リングせん断試験機のせん断箱の模式図

Fig. 10 Schematic illustration of shear box of undrained ring shear apparatus 

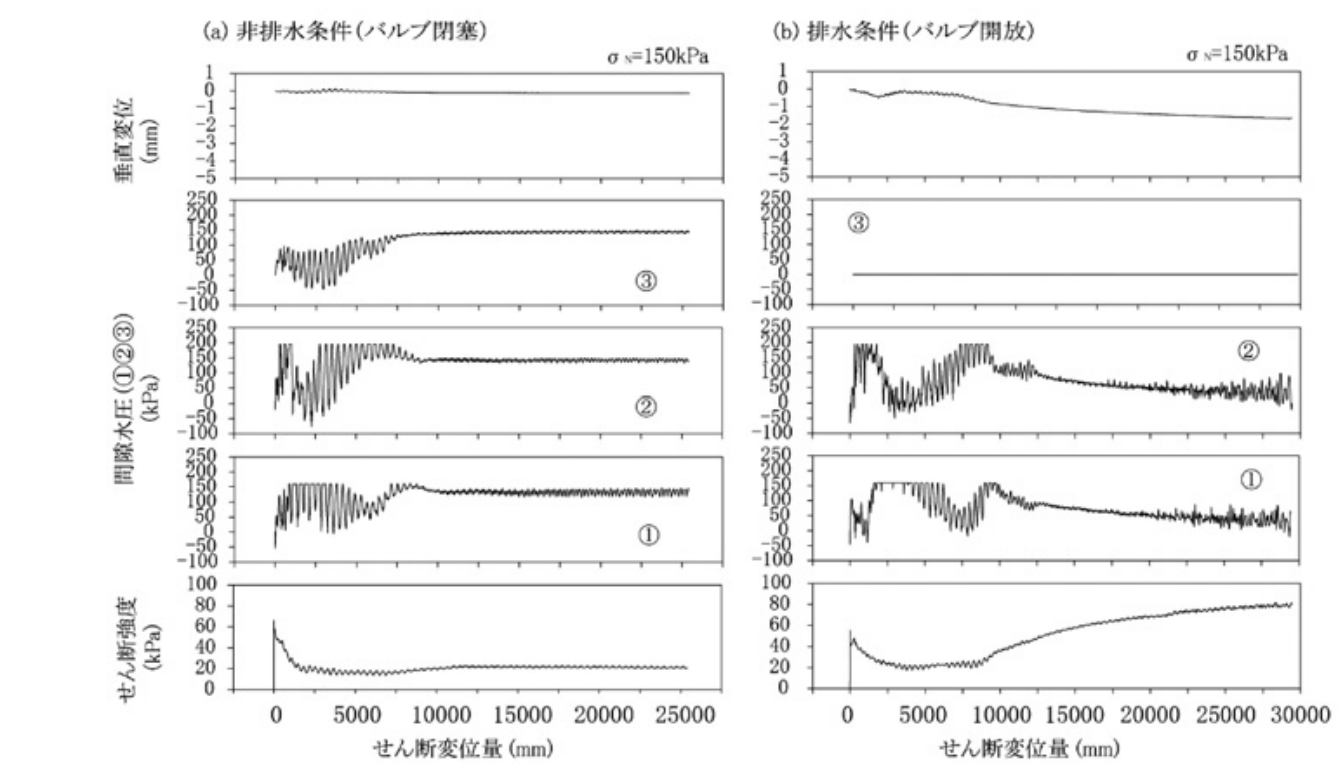

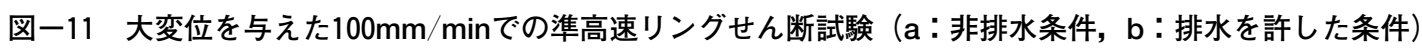

Fig. 11 Fast ring shear tests under (a) undrainedand and (b) drained conditions

状況が確認された。せん断ゾーンの含水比が液性限界と 塑性限界の中間值付近まで上昇し（図-9），水槽の自 由水が試料のせん断ゾーンに取り込まれたものと考えられる。

\section{3 高速せん断時のせん断ゾーンの間隙水圧挙動の 検証（検証実験 2 )}

以上の一連の粘性土の負の速度効果について, 高速せ 几断時の強度低下がせん断面付近の過剩間隙水圧上昇に 起因するのかどうかを明らかにするため，せん断面付近 の間隙水圧計測を試みたリングせん断試験を行った。柴 崎ら（2003）が改良した非排水条件での試験が可能なリ ングせん断試験機を用い， $100 \mathrm{~mm} / \mathrm{min}$ の一定速度で 25 $\mathrm{m}$ 以上の大変位を与えた実験を行った。当試験機は, 上 下リング間を $490 \mathrm{~N}$ 前後の荷重で常時圧接しているため, せん断面からの試料流出や水の出入りがない構造となっ ている (図-10)。実験は, 非排水条件㧍よび排水を許 す条件でそれぞれ行い，排水条件の試験では，供試体上

半固体 WP 塑性体 WL 液体

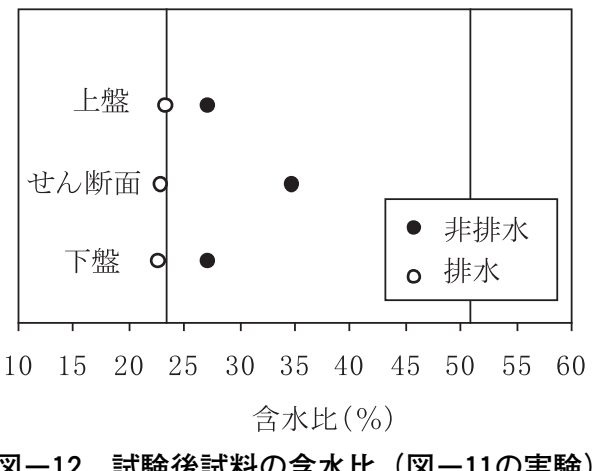

Fig. 12 Water contents of specimens around shear zone (data of the Fig. 11experiment)
面側の排水弁を開放し排水を許した。載荷盤側から挿入 したニードルを介して，せん断面付近の間隙水圧（1), (2) 計測も行い，供試体上面の水圧（3) の計測も併せ て行った。

実験に用いた試料は，木下ら（2009）が用いた塩谷神

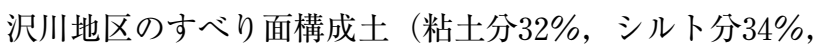

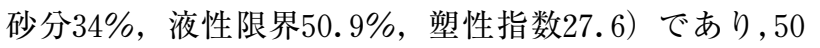
$\mathrm{mm} / \mathrm{min}$ 以上の速度で負の速度効果が確認されている。 正規圧密条件, 垂直応力 $150 \mathrm{kPa}$ 一定とした実験結果を, 図-11(a)，（b)に示す。両条件ともせん断初期は水圧 の変動が複雑で不安定であるが, 載荷盤側の排水弁を閉 じた非排水条件では, 250 分間以上に渡り $25 \mathrm{~m}$ の大変位量 を経ても大きな過剩間隙水圧が維持され, せん断強度が 低いままであった。間隙水圧が安定するまで水圧変動が

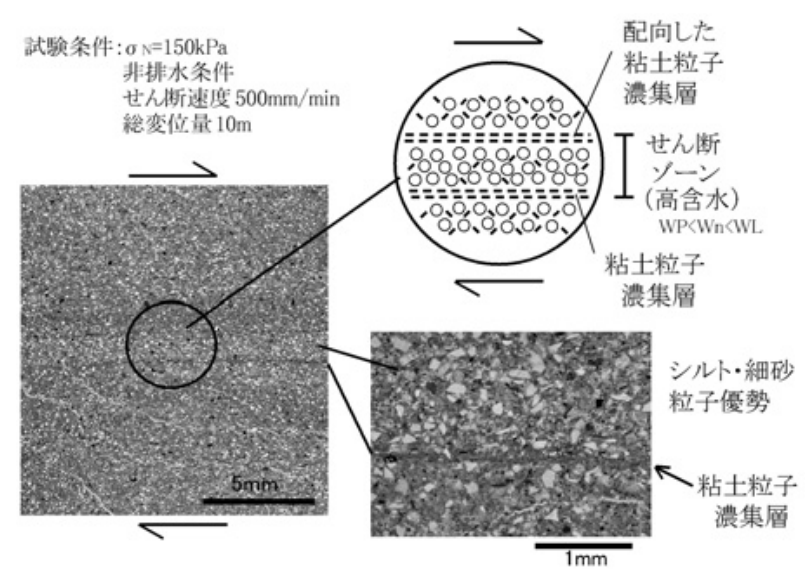

図ー13 リングせん断供試体の薄片写真とせん断ゾーンの模 式図

Fig. 13 Thin-section of test specimen and schematic illustration of the shear zone 

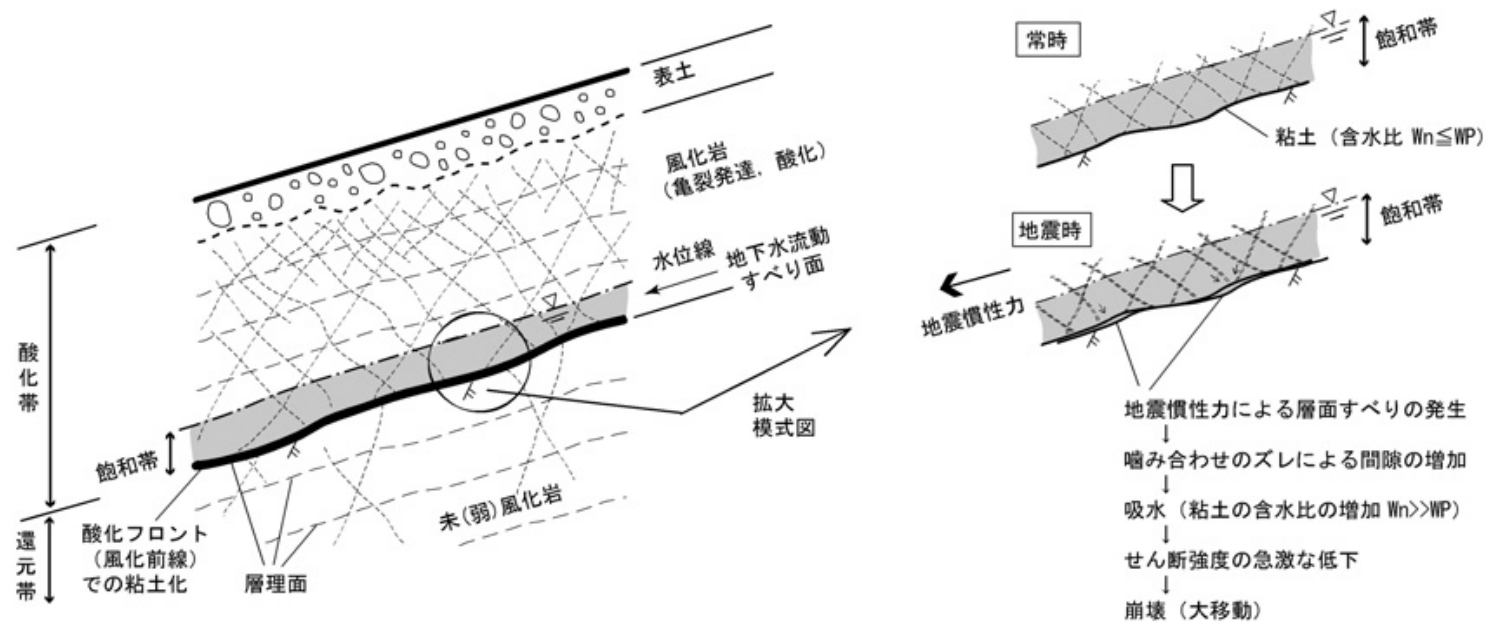

図-14＼cjkstart地震時のすべり面の強度低下機構の模式図

Fig. 14 Schematic illustration of mechanism of shear strength weakening during the earthquake

激しく，センサーの計測容量を越える水圧も瞬間的に発 生している。図では，センサーの計測最大值を超えた部 分はカットオフとして現れている。前半にみられる水圧 の細かい変動はリングせん断試験機の回転周期（1 回転 $392 \mathrm{~mm}$ ）に伴うもので，試験供試体厚が $360^{\circ}$ 厳密に均 質でないことが要因として考えられるが，長時間せん断 を継続することで, せん断ゾーンの発達や試料厚の均質 化などにより安定な挙動を示したと考えられる。一方， 排水弁を開放し排水を許す条件では，時間経過に伴い， せん断面付近の過㮃間隙水圧の消散が進み，せん断強度 も低速せん断時のレベルまで上昇し, 収束していく様子 が確認された。また，試験後の試料の含水比の計測によ ると（図-12), 非排水条件の試料は, せん断ゾーンの 含水比が高く，塑性限界を大きく上回る值を示した。一 方，排水を許した試験では，せん断ゾーン及びその上下 の含水比とも塑性限界付近に低下しており, 数時間かけ てせん断ゾーンから脱水が進み, 密度が増加したことを 示している。検証実験 1 も含め，高速せん断時の強度低 下は，せん断ゾーンにおける含水比の上昇を常に伴って おり, 含水比の増加がなければ例え高速条件でも強度低 下が起きにくいことを示している。

図－13は，同一試料を用い，別途実施したリングせん 断試験（正規圧密条件, 垂直応力 $150 \mathrm{kPa}, 500 \mathrm{~mm} / \mathrm{min}$, 非排水条件，総変位量 $10 \mathrm{~m} ）$ 後の供試体断面の薄片写真 である。 2 〜 mm厚のレンズ状のせん断ゾーンが認め られ，その上下端に細かい粘土粒子の濃集部があり, せ ん断ゾーン内部にシルト・細砂粒子に富む様子が確認で きる。強度低下時にせん断ゾーン内部が高含水状態と なって軟質化 (流動化) し，過剩間隙水圧の発生場となっ たと考えられる。このような透水性の不連続を伴うせん 断ゾーンの発達は，せん断ゾーン内部から上下方向への 間隙水の移動を妨げ，過剩間隙水圧の消散を遅延させる と予想される。なお，この実験での上下リング間は，所
定の荷重で圧接しているため，せん断ゾーンの含水比増 加は，検証実験 1 のような，せん断箱外側からの水の浸 入が原因ではない。せん断ゾーン内部の含水比が上昇し た要因としては，せん断ゾーン上下に粘土濃集層が発達 し，せん断ゾーン周辺で粒子の分級や再配列が進み，間 隙率の不均一化が進んだ中で，図－12に示したように， せん断ゾーン内部の含水比が相対的に高まった可能性が 考えられる。上下の粘土濃集部は非常に薄いため，局所 的な含水比の評価が困難であるが，せん断ゾーン内部と 大きな差がある可能性がある。

\section{5. 風化軟岩層理面の地震時せん断強度低下メカニズム}

ニゴリ沢地区の現地調査や土質試験 (第 3 章), 中塑 性粘性土のせん断強度がせん断速度上昇により低下する (負の速度効果) メカニズムを検討した一連のリングせ 几断試験結果（第 4 章）を踏まえ，現地状況から推察さ れる風化軟岩層理面のせん断強度の低下メカニズムと地 震時地すべりの発生機構の概念図を図－14に示した。

近年発生した2003年宮城県北部地震，2004年新潟県中 越地震，2007年新潟県中越沖地震，2008年岩手宮城内陸 地震などでは，新第三紀の堆積岩地帯において，特定の 層理面を境に岩盤が押し出した事例が多数報告されてい る（例えば，橋本ら；2004，高橋ら；2005，野崎；2008， 日本応用地質学会調査団, 2009, 大丸ら；2011)。この ような層理面に沿う変位は層面すべりと呼ばれ，地震動 による初生地すべりの先駆的な現象と見なされ（野崎; 2008), 地震時に数 $\mathrm{cm}$ 数十 $\mathrm{cm}$ の変位量が確認され, 大崩壊にまで至らなかったものが多く存在する。そして， 地震による層面すべりの観察事例によると，層理面には 粘土フィルムの介在（橋本ら；2004，高橋ら；2005）や 湧水が観察されている（野崎；2008）。

層面すべりが大移動に繋がるかどうかを決定する要因 を解明する上で，層理面付近に賦存する地下水の関与が 
指摘できる。ニゴリ沢地区の 3 ブロックとも，すべり面 深度の上下近傍に地下水位を形成している調查孔が多い。 また，図－ 5 に示した I ブロックでの食塩水検層や温度 検層結果より, 恒常的な地下水流動層が地震前より存在 したと考えられる。検証実験 1 （図－8）に示したよう に，水槽側から流入した水がせん断ゾーン（層理面沿い に分布する粘性土層）の含水比を高めるような現象が害 斜面でも起これば，大移動につながる可能性が高い。

また，すべり面付近の粘性土の含水比が上昇するプロ セスに，層理面の起伏（凹凸）が影響すると推察される。 図ー14の模式図に示したように，岩盤不連続面は大なり 小なり起伏を伴っており, 地震慣性力により変位がわず かでも発生すると, 不連続面の噛み合い状態が切断され, すべり面付近に間隙が生じやすくなる。風化前線の酸化 フロントと一致する層理面沿いは粘土化が進み, 塑性限 界付近の含水比を示している。その状態に自由水が即時 あるいは時間を要して浸入することで，層理面沿いに分 布する粘性土が吸水して含水比が上昇し塑性化や流動化 を起こしやすくなると予想される

新潟県中越地震や岩手宮城内陸地震で発生した流れ盤 地すべりは，ニゴリ沢地区を含め，巨視的にみると斜面 上部よりも斜面下部や末端部の幅が大きい末端開放型斜 面が多い。地すべり移動に伴い側方に伸張しながら移動 体岩塊の転倒や解体が短時間に進むような地盤条件では, すべり面付近の間隙の増大や，図ー12に示したようなす べり面への自由水の浸入が容易に起こると予想される。 地震時に数 $\mathrm{cm}$ の変位量で留まるような層面すべりは, 主に振動中の地震慣性力の作用による変位が主体と思わ れるが，地下水に飽和したような条件では，すべり面付 近の粘性土（粘性土状風化岩）の含水比が徐々に高まり, 地震動が収まった後にも大移動に繋がる可能性がある。 検証実験 2 （図－11）に示したように，一度高含水状態 となり強度低下した粘性土試料は, 間隙水圧の消散が遅 く, 長距離移動を起こしやすいものと予想される。現時 点では推論の部分が多いが, 以上のような場の条件を再 現した模型実験などのアプローチにより今後検証が可能 と考えられる。

加えて, 初生的な層面すべりが発生し移動量が少ない ような斜面でも, 噛み合わせのズレにより間隙が増大し た不連続面が, 将来的には地下水流動の経路となり, 層 理面沿いの風化の進行や, 長期的には流入粘土の集積な ども促す可能性がある。層理面のせん断強度を長期的に 低下させる要因となることから, 層面すべりが確認され た斜面の追跡調査なども進めていく必要がある。

\section{6. まとめ}

2008年岩手・宮城内陸地震で発生したニゴリ沢地すべ り地に扔ける現地調查㧍よびすべり面構成土の土質試験, 他地区の同様な土質特性を示す粘性土試料を用いた土質 試験結果より，以下の知見が得られた。
1）すべり面せん断試験およびリングせん断試験より, ニゴリ沢地すべりのすべり面のせん断抵抗角は， $16^{\circ}$ 前 後であった。木下ら（2009）が報告した新潟県中越地震 の塩谷神沢川地すべり同様， $500 \mathrm{~mm} / \mathrm{min}$ のんん断速度 で急激に強度低下するリングせん断挙動が確認された。 このような土質特性が，地震時の大滑動に大きく関与し た可能性が高い。

2）試験供試体を浸水した条件と，浸水しない条件での 沉用型の試験機を用いてのリングせん断試験結果による と, 浸水した条件では, 高速せん断時に大きな強度低下 が確認された。Tika et al.(1996) が考察したように, せん断ゾーンへの自由水の浸入とそれに伴うせん断ゾー ンの含水比増加が, 強度低下の要因であると考えられる。 3 ）非排水条件および排水を許す条件で, $25 \mathrm{~m}$ 以上の大 変位を与えたリングせん断試験を $100 \mathrm{~mm} / \mathrm{min}$ のせん断 速度で行った。高速せん断中は，せん断ゾーンの過剩間 隙水圧の上昇が確認され, せん断ゾーン内部の含水比上 昇による軟質化も認められた。また，排水を許しながら 長時間せん断させると, 最終的には, 過剩間隙水圧が消 散し, せん断強度の回復も確認された。せん断ゾーンの 含水比の増加がなければ大きな強度低下が起きにくいこ とが判明した。

4) 風化軟岩の流れ盤斜面における地震時地すべりの発 生機構を検討した。地震慣性力の作用により層面すべり が発生すると，層理面の起伏の乗り越えに伴い，増大し た間隙に自由水が浸入しやすくなる。層理面沿いに分布 する粘土化した強風化岩の含水比が増加し, せん断強度 の急激な低下をもたらすことが，大移動を起こす地すべ りの要因であると推察した。また, 地震時に大移動を起 こした流れ盤地すべりの層理面付近に顕著な地下水流動 が確認されることから, 地震時の地すべりの移動量に地 下水環境が大きく影響していると考えられる。

\section{謝辞}

本研究の成果は, 東北森林管理局岩手南部森林管理署 が実施した調查結果に, 追加の室内試験・分析の結果を 加えとりまとめたものである。調查実施にご協力頂いた 関係各位に，ここに記して謝意を表します。

\section{引用文献}

大丸裕武 - 村上亘 - 多田泰之 - 岡本隆 - 三森利昭 - 江坂文寿 （2011）：2008年岩手 ·宮城内陸地震による一迫川上流域の崩壊 発生環境. 日本地すべり学会誌, Vol.48, No. 3, pp. 23-36.

橋本修一 - 山口和英・高橋豊治・葛木健大 (2004)：2003年 7 月 26 日宮城県北部地震時の岩盤斜面の挙動. 日本応用地質学会, 平 成16年度研究発表会講演論文集, pp. 193-196.

木下篤彦 - 山口真司 - 山崎孝成 $\cdot$ 柴崎達也 - 小島健 ·吉松弘行 （2009）：2004年新潟県中越地震により大滑動した地すべりのす ベり面の土質特性に関する研究. 日本地すべり学会誌, Vol. 45, No. 6, pp. $6-15$.

木下篤彦・柴崎達也・橋本純 - 長谷川陽一 - 三森利昭 - 岡田康彦 (2012)：2008年岩手・宮城内陸地震により発生した栗原市耕英 地区崩壊地の地盤特性. 砂防学会誌, Vol. 65, No. 2, pp. 3-11. 
國生剛治・石澤友浩（2010）：地震時斜面崩壊における土塊流動距 離のエネルギー的評価法と実崩壊例への適用. 日本地すべり学 会誌, Vol.47, No.3, pp. 121-128.

眞弓孝之・柴崎達也・山崎孝成（2003）：すべり面せん断試験によ るすべり面のせん断強度評価. 日本地すべり学会誌, Vol.40, No. 4, pp. $273-282$.

日本応用地質学会平成20年岩手 ·宮城内陸地震調査団 (2009)：「平 成20年岩手 ·宮城内陸地震」災害第一次現地調査報告, 応用地 質, Vol. 50, No.2, pp. 98-108.

野崎保（2008）：2007年新潟県中越沖地震による初生的岩盤地すべ りと層面すべり, 日本地すべり学会誌, Vol.45, No. 1, pp. 72 -77 .

齊籐龍太・佐々恭二・福岡浩 (2007)：珪砂・ベントナイト混合試 料における内部摩擦角の速度効果. 日本地すべり学会誌Vol. 44, No. 1, pp. $33-38$.

柴崎達也 - 眞弓孝之・山崎孝成（2003）：間隙水圧計測を目的とし たリングせん断試験機の開発. 第38回地盤工学研究発表会発表 講演集, pp. $231-232$.

柴崎達也・長谷川陽一・山崎孝成（2009）：中越地震で再活動した
地すべりの土質特性と前回の地すべりイベントの年代について. 第48回日本地すべり学会研究発表会講演集, pp. 185-186

Skempton A. W. (1985) : Residual strength of clays in landslides, folded strata and the laboratory. Geotechnique, Vol. 35, No. 1, pp. $3-18$.

高橋明久·森屋洋 · 荻田茂 ·阿部真郎 - 山田孝雄 · 原口強 （2005）：2004年新潟県中越地震によりーツ峰沢に発生した岩盤 地すべり, 日本地すべり学会誌, Vol.42, No.2, pp. 121-128.

Tika T. E., Vaughan P. R. and Lemos L. J. L. J (1996) : Fast shearing of pre-existing shear zones in soil. Geotechnique, Vol. 46, No. 2, pp. $197-233$.

Tika T. E. and Hutchinson J. N.(1999) : Ring shear tests on soil from the Vaiont landslide slip surface. Geotechnique, Vol. 49, No. 1 , pp. $59-74$.

王功輝・末峯章・陳光斉（2010）：徳島県白石地すべり地における 蛇紋岩の残留強度特性および移動土塊の変動メカニズムについ て. 日本地すべり学会誌, Vol.47, No. 5, pp. 265-273. （原稿受付2011年 9 月 5 日，原稿受理2013年 1 月 30 日） 